Guilherme C. Silva, Tales Tomaz

\title{
BIG DATA AS "PRACTICAL ONTOLOGY”: THE ONTOTHEOLOGY UNDERLYING THE INTERPRETATION OF REALITY AS DATA
}

\author{
Department of Humanities \\ York University \\ 4700 Keele Street - M3J1P3 \\ Toronto, ON - Canada \\ +16478773524 / gcsilva@yorku.ca \\ Department of Communication Studies \\ University of Salzburg \\ Sigmund-Haffner-Gasse 18 - 5020 \\ Salzburg - Austria \\ +436628044 4195 / tales.tomaz@sbg.ac.at
}

The article discusses the emergence of a "practical ontology" in some of the most triumphalist discourses on Big Data. Such an interpretation can be drawn from the Heideggerian critique of ontotheology, a term he used as an equivalent to Western metaphysics. Following his perspective, the article argues that the reduction of reality to data, as in many Big Data discourses, means putting functionality as the fundamental aspect of beings, hence - the idea of a practical ontology. The Heideggerian critique of ontotheology, however, not only makes the ontological core of Big Data's practical discourses more transparent but also points out the theoretical limits of that ontology and, furthermore, of most discourses around Big Data. It could be said that eventually Big Data's practical ontology conceals the very moment of unconcealment of beings as data, undermining a proper comprehension of its object of analysis - the data.

KEYWORDS: Big Data, practical ontology, Martin Heidegger, metaphysics. 


\section{Introduction}

This paper aims to analyse philosophical implications of common discourses centred around data that construe them almost as a transparent way of interpreting reality, as is the case in most triumphalist narratives focusing on the social appropriation of digitally generated data, so-called Big Data. The theoretical framework for this procedure stems from Martin Heidegger's philosophy, especially his deconstruction of metaphysics as ontotheology. By reducing reality to data as some Big Data discourses do, they consider functionality as the fundamental ground for beings. In this sense, we are facing the emergence of a "practical ontology". However, what are the theoretical limitations of such an ontology, considering Heidegger's philosophical framework? This paper deals with this question and advances a critique of the practical ontology of Big Data in the light of Heidegger's criticism of Western metaphysics as ontotheology.

First, the article presents a short overview of the emergence of Big Data, drawing upon relevant literature on the theme, such as the influential works of Rob Kitchin (2014), Viktor Mayer-Schönberger and Kenneth Cukier (2013), danah boyd and Kate Crawford (2012), and others. This section seeks to elucidate different ways in which the narratives around Big Data can advance a practical ontology, whereby the nature of beings is defined solely in terms of their functionality. Subsequently, we will present Heidegger's critical take on Western metaphysics, emphasising his interpretation of it as ontotheology, a mode of knowledge that seeks to provide an ultimate ground for beings (Heidegger 1969). Finally, the paper relates Heidegger's criticism of ontotheology to the practical ontology that underlies Big Data narratives, stressing the essentialist, technological, and reductionist character of this ontology.

\section{The emergence of Big Data}

The Data Transfer Project, an initiative by Google and other Internet giants, such as Facebook, Twitter, and Microsoft, gathered a significant database of the four companies under a single platform. In the official report of what is already the biggest data portability project ever, such terms as "velocity", "efficiency", "size", and "transparency" are constantly reaffirmed to be the project's natural outcome ${ }^{1}$. This association of ideas around data reproduces Doug Laney's (2001) original approach of the three 'Vs': velocity, variety, and volume. Later contributions add elements like

1 Willard, B., Chavez, J., Fair, G., Levine, K., Lange, A., Dickerson, J. 2018. "Data Transfer Project: from theory to practice". [pdf] Data Transfer Project. Available at: <https://services.google.com/fh/files/ blogs/data-transfer-project-google-whitepaper-v4.pdf> [Accessed 30 June 2021]. 
veracity and exhaustivity in reference to the "era" of Big Data (Kitchin 2014; MayerSchönberger and Cukier 2013). The term appears in popular news outlets, such as The New York Times ${ }^{2}$, Washington Post ${ }^{3}$, and The Guardian 4 , accompanied with superlatives carrying an aura of the solution to humanity's problems. The arrival of the era of Big Data would offer companies, consumers, and public institutions infinite resources that, if used wisely, would result in a better capitalism and stronger democracy. Despite the recent boom in its use, the term first appeared during the 1990s in the context of informal meetings that took place in tech companies in the Silicon Valley to refer to datasets whose volume was too large for just one machine to process. In any case, "the expression started to refer [in recent times] to a sociotechnical conjuncture" in which data analysis "exercises a central role in the global sociopolitical context" (Silva 2018: 109). Big Data ended up being used to describe almost a natural force to be captured by humans with the help of technology, an epistemological revolution capable of overcoming causal knowledge with the use of replicable data in research, and a new era with new ethics and beliefs (Puschmann and Burgess 2014).

However, calling data "big", "complex" or "varied" says little about what data is. In the words of boyd and Crawford (2012: 663): "Big Data is, in many ways, a poor term". Instead of providing an accurate definition of Big Data, these corporate descriptions actually state how we should position datafication socially and politically. Furthermore, these new accounts draw upon historically articulated meanings of the word "data". Cornelius Puschmann and Jean Burgess (2014) indicate that the word data has been, since the Greeks, associated with the scientific mode of knowledge [ $\dot{\varepsilon} \pi \iota \tau \tau \dot{\mu} \mu \eta]$ as something to which its unconcealment is given beforehand ${ }^{5}$. The Greeks saw data as something that is given, at hand, the "substance to be analysed and probed to which a prior essence is assumed" (Silva 2018: 109). For Rafael Capurro (2006: 4), that is the paradigmatic character of mathematical natural science. The use of data is not the mere application of mathematics to natural processes but "the prior projection of the entities it discovers". Here, data provides the "basis for reasoning or calculation" (Swan 2015: 469).

2 Lohr, S. "How Big Data became so big". 2012. Available at: <https://www.nytimes.com/2012/08/12/ business/how-big-data-became-so-big-unboxed.html? mtrref=www.google.com\&gwh=618CCD0E9C 6F903C77A70CAB133D6CFA\&gwt=pay> [Accessed 20 September 2021].

3 Song, B. "Big Data as the next public good”. 2018. Available at: $<$ https://www.washingtonpost.com/news/ theworldpost/wp/2018/05/02/big-data/?utm_term=.e813a6127e6b> [Accessed 20 September 2021].

4 Burn-Murdoch, J. "Big Data: what is it and how can it help?". 2012. Available at: <https://www.theguardian.com/news/datablog/2012/oct/26/big-data-what-is-it-examples > [Accessed 20 September 2021].

5 Puschmann and Burgess (2014) point out to the Greek word $\delta i \delta \omega \mu$ as the root for the word data. In Latin, it was translated as datum, to which the English term data has a direct connection. 
Data, serving as the basis of mathematical reasoning, not only is understood as what is given beforehand but also provides a clear picture of reality. In other words, data must "be one" with the reality it refers to. For this reason, this meaning of data can also imply access to truth that is more direct than other modes of knowledge, such as philosophy and religion. Data science based on the storage and analysis of Big Data is believed to overcome any infertile philosophical reasonings. After all, "who knows why people do what they do? The point is they do it, and we can track and measure it with unprecedented fidelity. With enough data, the numbers speak for themselves" (Anderson 2008; cf. Mayer-Schönberger and Cukier 2013). In all these "it-works" approaches, quoting Alistair Croll (2012), the rule is to "collect [data] first and ask questions later".

It is clear that not every data science is based on a belief in data transparency or "rawness" (Bowker 2005). Recent literature on Critical Data Studies has recognised the need to view Big Data as more than just a technical, commercial and "neutral" revolution. These accounts focus on such issues as the Global South-Global North divide, reinforced by data practices (Mann, Devitt and Dale 2019; Milan and Treré 2019) and the relation of data to new forms of capitalism (Fuchs and Chandler 2019), for example. However, there is an aspect that remains overlooked in most of the Critical Data Studies accounts: the implied sense that beings are necessarily in one or another way reproducible with data. In those triumphalist Big Data discourses, if data is what is given prior to analysis, it must be, above all, replicable, notwithstanding specific contexts or procedures. That notion is rooted in the idea that, by correlating different datasets, we could "capture the present and predict the future" (Mayer-Schönberger and Cukier 2013: 35). The possibility of replication and, thus, accurate prediction implies that things have an absolute intrinsic identity that can be "saved" and reproduced (Ekbia et al. 2015). Therefore, not only does Big Data represent analytical solutions or a massive amount of data but it also implies a certain vision of the constitution of beings and, consequently, a particular form of ontology. But what kind of ontology is presupposed in these Big Data narratives? We suggest that some aspects of Heidegger's criticism of metaphysics provide important insights concerning ontological implications of Big Data discourses.

\section{Heidegger and the ontotheological constitution of metaphysics}

To understand how Heidegger interprets metaphysics better, it is important to reassess, at least generally, Heidegger's understanding of Being, as his philosophy and the context within which he develops his interpretation of metaphysics - is 
intended to address the question of Being in Western thinking. The philosopher differentiates between Being [Sein] - in uppercase in most English translations and being [Seiende] - in lowercase. He is interested in underscoring this difference, meaning that Being [Sein] cannot be the same as a being [Seiende], be it a person, an idea or a supreme being such as God. Being in uppercase would be better understood through the verb to be. The question of Being is the question of what it means to say that beings are.

For Heidegger, every attempt to even name things is necessarily preceded by the fact that a certain understanding of Being "touches" us. "We are able to grasp beings as such, as beings, only if we understand [beforehand] something like [B] eing" (Heidegger 1982: 10). It is precisely this previous knowledge, implicit in our everyday lives, that allows us to interact with the world and other people. Without this prior knowledge - which Heidegger calls "understanding of Being", - we would not be able to pronounce even one word since the words we use to refer to beings are derived from a previous comprehension of their Being (Heidegger 1996: 3-4). It is, therefore, necessary that Being is unconcealed beforehand so that we can understand beings as such.

For Heidegger, there is one kind of being to whom Being unconceals itself, allowing beings to appear as such. He names this kind of being as Dasein, usually translated into English as being-there (Heidegger 1996). In short, Heidegger considers Dasein as the kind of being that human beings are, i.e. beings who encounter beings as beings and, therefore, to whom the question of Being is open. However, as everything that we meet daily is a being, we tend to forget that the openness of Being is what allows us to encounter beings as beings. The understanding of Being "cannot have been derived from those encounters or those beings. It cannot be seen, then, in any way as a body of empirical information", which we can measure (Nicholson 1996: 357). The very idea of questioning how this understanding occurs is rejected by Heidegger, since asking questions can only derive from a previous unconcealment of the beings in question. Being is what unconceals beings as beings, but by doing that, it conceals itself. An illustrative example of this phenomenon, given by Heidegger, comes from the mirror. In order to reveal its image, the mirror's surface needs to disappear as "a mirror" (Heidegger 2000: 48).

For the sake of our argument here, the importance of Heidegger's reasoning for the ontological difference between Being and being comes from the recognition that any attempt to provide an ultimate ground for beings can never be deduced

6 The difference between Being and beings is called in Heidegger's texts the ontological difference. A more thorough discussion of ontological difference and its importance in Heideggerian philosophy can be found in Nicholson 1996. 
from a rational analysis of beings themselves. We can only refer to beings based on a particular disclosure of their Being to us. This disclosure could also be understood as a moment of "discovery", which is never at reach for us. We can never recall the second when we discovered the beings we get in contact with in our everyday lives. Furthermore, every attempt to provide an ultimate ground for beings is a reduction of our experience with them, an implicit trust in the capacity of the human consciousness to apprehend reality beyond the unconcealment of beings themselves.

It turns out that the history of Western civilisation, for Heidegger, is marked by an ongoing endeavor to provide an ultimate ground for beings. Heidegger calls this history "metaphysics". Metaphysics "grounds an age, in that through a specific interpretation of what is and through a specific comprehension of truth it gives to that age the basis upon which it is essentially formed" (Heidegger 1977: 115). In the West, this task involved answering questions like "in what way is a being a being and which is the ultimate being?" (Heidegger 1998: 340).

The first is an ontological question, whereas the second is a theological one, as Ian Thomson (2000) summarised in his interpretation of Heidegger's metaphysics. For Heidegger (1969: 70), metaphysics thinks ontologically when it seeks what is "common to all beings as such". On the other hand, when metaphysics thinks theologically, it searches for a being that serves as the highest entity, a supreme being, that "accounts in the sense of giving the first cause" for all beings (Heidegger 1969: 70). This theological account presents uppercase Being as the supreme being beyond which there is nothing. The structure of Western metaphysics is therefore ontotheological. In short, the historical role of metaphysics is primarily that of establishing and disseminating a necessary ground for things.

The problem with metaphysics, according to Heidegger, is what he calls the "forgetfulness of Being." By seeking to establish a ground for beings, metaphysics makes us forget that the event of Being - that unconceals beings to us - cannot be observed nor measured. We are never in a condition to define Being or decide what it might be. Being is, in other words, undecidable. Every attempt to ground beings from "God's perspective" or "God's eye" is, therefore, a reduction of the original undecidability of Being. In that regard, every metaphysics is an arbitrary attempt to, in Thomson's words, "arrest a being's dynamic phenomenological manifestation, freezing it into a pre-conceived permanent presence" (Thomson 2000: 317). Ironically, each effort to provide a ground for beings is only possible thanks to the event of Being. Therefore, all Western metaphysics are manifestations of our previous unreachable knowledge of Being, even as the Being conceals itself (Marchart 2007).

In Heidegger's perspective, the current technological age marks the consummation of metaphysics, the highest point of metaphysics' "forgetfulness 
of Being” (Heidegger 1977). This view stems from his belief that we should not interpret technology as a means to an end or a neutral tool. In his words, technology "is a way of revealing" beings, bringing them from unconcealment to concealment (Heidegger 1977: 12). Employing tools or instruments, in Heideggerian philosophy, is not just a matter of achieving a particular goal. Before and surrounding the act of employing technology, in his account, there is an understanding that what is unconcealed is necessarily something that can be arranged and rearranged through technical procedures. The more the technological knowledge advances, the more universal is the impression that being means to be at disposal for arrangement. The technological age for the German philosopher is therefore the moment when beings are only conceived as "standing-reserve". If beings are conceived as "standingreserve", they are beings as such only to the extent they can function within the given framework.

In the following part, we argue that this technological metaphysics is strongly instantiated in Big Data's discourses of practicality, immediacy, and transparency, making it a contemporary version of ontotheology that forgets that Being is something that we are not able to grasp.

\section{"Practical ontology" of Big Data as ontotheological metaphysics}

As we started to argue in the previous part, Big Data's practical ontology closely resembles Heidegger's understanding of metaphysics. The first aspect to consider is that contrary to what some may affirm, many sophisticated claims around "practical ontologies" are, in fact, essentialists. When one affirms, for instance, that beings can onlybe understood through their actions, functions, or practices, rather than through their fixed essences, they still make claims about the nature of these beings and, in so doing, define Being. Thus, they operate within the metaphysical framework. As Heidegger (1998: 250) stated, "the reversal of a metaphysical statement remains a metaphysical statement." Even if fostered by a desire to overcome abstractional "ontological" thinking (Dubois, Hájek and Prade 2000) or the subject-object divide, the effort to replace old universals, deemed infertile, with functionality and action as fundamental grounds for beings is still quite ontological. Even if some argue that "practical ontology implies no essentialism, radical or otherwise. Since the starting point is that ontologies emerge due to action and practice, transformation is implied in its very definition" (Gad, Jensen and Winthereik 2015: 76), proposals like these are still essentialist since they provide an ontological ground for beings, something that is common to all beings amidst the rhetoric of "multiplicity" or 
"multiple natures": to act, to perform, to function. They try to define what beings are from an "outsider's point of view".

As argued before, the discourses around the "Big Data era" are a clear example of a particular way of revealing beings as raw materials to be assessed and organised through their functionality. As a way of providing a ground for beings, our present technological age and its ultimate belief in data as the supreme way of grasping reality is nothing but a manifestation of what Heidegger understood as metaphysics: an attempt to provide an ontologically and theologically ultimate ground for beings. In this age, other "truths" apart from the "truth" of technical efficiency are seen as untenable. Everything, even what is still to be known, appears as a problem whose solution can only be reached from a functional perspective. It is only through the technical lenses that beings appear. Perceiving beings based on their performance is a perfect example of metaphysics in operation, as it reunites all beings under a common ontological "umbrella". Therefore, Big Data discourses that draw attention to the functionality of beings, advancing a form of practical ontology, still possess the characteristics of metaphysics in the ontotheological sense (as argued by Heidegger).

However, viewed from the Heideggerian perspective, the most critical aspect of the practical ontology in Big Data discourses is its reductionism. Construing beings as functions, actions, and practices is as much a reductionist approach as any other metaphysical account. In Big Data's practical ontology, beings are reproducible, as they can be transformed into data and, as such, exchanged. However, beings can only be reproducible and exchangeable when there is a common ontological ground that unites them. The ontological difference showcases that this reproducibility can only be a derived aspect of our primordial relation with Being and beings. This is a point in Heidegger's thought that Jean-Luc Nancy and Hans Ulrich Gumbrecht developed further. According to them, there is an increasing shift from the realm of materiality, arts and aesthetics to functionality and reproducibility.

Nancy points to the fact that "before all representational grasp, before a consciousness and its subject, before science, and theology, and philosophy, there is that: the that of, precisely, there is. But 'there is' not itself a presence, to which our signs, our demonstrations, and our monstrations might refer" (Nancy 1993: 4, italics added). By trying to grasp and represent everything, Western metaphysics ends up framing beings in an eternal presence. However, as Nancy highlights, these attempts at representation only occur after the intangible and unique manifestation of each being (what he calls "birth to presence"). Originally, beings cannot be represented "in the mode of 'being' [as a substance] nor in that of 'there' [as a presence]" (Nancy 1993: 4). That is a radically different perspective from the one advertised by Big 
Data prophets. While in the current "datafied" metaphysics there is a widespread belief that everything can be represented, the irreproducibility of Being and the underlying recognition of the metaphysical nature of ontotheology reveal that nothing can be reproduced.

Hans Ulrich Gumbrecht provides a similar reflection. Emphasising materiality as one of the fundamental aspects of the being's coming to presence, Gumbrecht (2003: 74) points out that "only the presence of certain things opens up the possibility of other things appearing in their primordial material qualities - and this effect might be considered as one way [and as a part] of unconcealing their Being". From a material point of view, nothing is replicable. The problem with conceiving beings only in terms of functional utility is that it amplifies a dichotomy between "the purely material surface of the signifier and the purely spiritual (or conceptual) depth of the signified" (Gumbrecht 2003: 40-41). This philosophical view, for instance, grounds the belief that, by grasping the conceptual meaning of something like a conversation with a friend, one could replicate the same experience in several different ways, such as through smartphones. In so doing, by storing and analysing large quantities of data, Big Data is said to offer what was previously unthinkable: an "accurate" reproducibility to such an extent that it is even possible to predict future phenomena.

Following Heidegger's philosophy in the sense that Nancy and Gumbrecht do, however, each event of Being is unique and underived. The problem emerges out of the project of metaphysics that tries to reunite everything under an eternal presence by taking to the limits our "forgetfulness" of the difference between Being and beings. That is precisely what Heideggerian philosophy wants to avoid, since "the origin of the difference can no longer be thought of within the scope of metaphysics" (Heidegger 1969: 71).

If, however, Big Data's practical ontology insists on focusing on the reproducibility of beings, it is because, as in every ontotheological metaphysics, it operates and relies on a forgetfulness of Being. The ultimate concealment that such an ontology provides is eventually the concealment of the event of Being itself and, as such, of the original undecidability coded in our relation to beings.

The irony of this reasoning is that, by forgetting Being, Big Data's practical ontology overlooks the very moment that enables grasping beings as data. As beings rendered data is a reduction derived from the original manifestation of Being, data can only be apprehended as such - in the whole ontological depth that it implies if we are still able to uphold the ontological difference and the non-coincidence between data and Being. In this sense, a practical ontology ends up ignoring data as data, i.e., as beings unconcealed specifically in this way by Being. The reductionism 
of this ontology impedes a better understanding of the conditions of the possibility of data itself, which very likely undermines the fulfilment of any serious effort towards any form of critical data science.

\section{Conclusion}

Within the last few decades, the so-called Big Data emerged, a catchphrase used to describe all sorts of systems and structures that deal with large amounts of data for its collection, interpretation, and use. In all the hyperbolic narratives structured around Big Data, as we have seen, there is an implicit (sometimes explicit) understanding that data renders reality "transparent", being an objective mediator for accessing the truth about things, overcoming old systems of thought and "useless" metaphysical abstractions. However, this vision entails an understanding of what constitutes beings, which means it is metaphysical per excellence.

The ontological claims in these Big Data narratives and their philosophical shortcomings are explicit in the light of Heidegger's critique of Western metaphysics, or "ontotheology". However, from a Heideggerian standpoint, such ontotheology, like any other, overlooks the fact that grounding itself is a subtraction, a case of forgetfulness that the moment we first captured as the "image of the world" is beyond our reach. This experience can never be fully captured be it by the name or by a sequence of numbers.

Maybe it is rather our "phenomenological numbness" (Thomson 2000: 317), a sense of distress than our incapacity of grasping what beings are that motivates us to capture the transitory movements around us into an eternal presence. This might be the main reason behind all attempts to provide an ontotheological ground for human existence and all the beings that encounter us, even if such a ground is the "non-ontological" practical ontology typical of the age of Big Data. The irony is that our awareness of such reality should not result in the "totalitarian temptation" to provide an ultimate ground for beings (Marchart 2007).

In the age of a practical and functional ontology, which relies on repetition and representation, the challenge set by Heidegger goes the opposite way. It seeks to strengthen the singular, unrepeatable, and calling for reflection in a different way from technical "problem-solving" reasoning. Otherwise we will never really be able to grasp what is at stake in the unconcealment of beings as data. 


\section{References}

Anderson, C. 2008. "The end of theory: the data deluge makes the scientific method obsolete", Wired, [online] Available at: <https://www.wired.com/2008/06/pb-theory/> [Accessed 29 June 2021].

Boyd, d., Crawford, K. 2012. "Critical questions for Big Data: provocations for a cultural, technological, and scholarly phenomenon", Information, Communication \& Society, 15 (5): 662-679.

Capurro, R. 2006. "Toward an ontological foundation of information ethics", Ethics and Information Technology, 8 (4): 175-186.

Croll, A. 2012. "Big data is our generation's civil rights issue, and we don't know it", Radar, [blog] August 2012. Available at: <http://radar.oreilly.com/2012/08/big-data-is-ourgenerations-civil-rights-issue-and-we-dont-know-it.html> [Accessed 29 June 2021].

Dubois, D., Hájek, P., Prade, H. 2000. "Knowledge-driven versus data-driven logics", Journal of Logic, Language and Information, 9 (1): 65-89.

Ekbia, H., Mattioli, M., Kouper, I., Arave, G., Ghazinejad, A., Bowman, T., Suri, V. R., Tsou, A., Weingart, S., Sugimoto, C. R. 2015. "Big Data, bigger dilemmas: a critical review", Journal of the Association for Information Science and Technology, 66 (8): 1523-1545.

Fuchs, C., Chandler, D. 2019. "Introduction: Big Data capitalism - politics, activism, and theory", in Fuchs, C. and Chandler, D. (eds.). Digital objects, digital subjects: interdisciplinary perspectives on capitalism, labour and politics in the age of Big Data. London: University of Westminster Press.

Gad, C., Jensen, C.B., Winthereik, B.R. 2015. "Practical ontology: worlds in STS and anthropology", ScienceCulture, 3: 67-86.

Gumbrecht, H. U. 2003. Production of presence: what meaning cannot convey. Stanford: Stanford University Press.

Heidegger, M. 1969. Identity and difference, translated by J. Stambaugh. New York: Harper \& Row.

Heidegger, M. 1977. The question concerning technology and other essays, translated by W. Lowitt. New York: Harper \& Row.

Heidegger, M. 1982. Basic problems of phenomenology, translated by A. Hofstadter. Bloomington \& Indianapolis: Indiana University Press.

Heidegger, M. 1994. Basic questions of philosophy: selected 'problems' of 'logic', translated by R. Rojcewicz and A. Schuwer. Indianapolis: Indiana University Press.

Heidegger, M. 1996. Being and time, translated by J. Stambaugh. Albany: State University of New York Press.

Heidegger, M. 1998. Pathmarks (GA 9), edited by W. McNeil. Cambridge: Cambridge University Press.

Heidegger, M. 2000. Introduction to metaphysics, translated by G. Fried and R.Polt. New Haven: Yale Nota Bene.

Inwood, M. 1999. A Heidegger dictionary. Oxford: Blackwell Publishers.

Kitchin, R. 2014. "Big Data, new epistemologies and paradigm shifts", Big Data \& Society, 1 (1): 1-12.

Laney, D. 2001." 3D data management: controlling data volume, velocity, and variety", BibSonomy [online] Available at: <https://www.bibsonomy.org/bibtex/742811cb00b303261f79a98e9b80bf49> [Accessed 30 June 2021].

Mann, M., Devitt, K., Daly, A. 2019. "Introduction: what is (in) good data?", in Daly, A., Devitt, K. and Mann, M. (eds.). Good data. Amsterdam: Institute of Network Cultures.

Marchart, O. 2007. Post-foundational political thought: political difference in Nancy, Leffort, Badiou and Laclau. Edinburgh: Edinburgh University Press.

Mayer-Schönberger, V., Cukier, K. 2013. Big Data: a revolution that will transform how we live, work and think. London: John Murray.

Milan, S., Treré, E. 2019. "Big Data from the south(s): beyond data universalism", Television \& New Media, 20 (4): 319-335. 
Nancy, J. L. 1993. The birth to presence, translated by B. Holmes. Stanford: Stanford University Press.

Nicholson, G. 1996. “The ontological difference”, American Philosophical Quarterly, 33 (4): 357-374.

Pentland, A. 2014. Social physics: how social networks can make us smarter. New York: Penguin Books.

Puschmann, C., Burgess, J. 2014. "Metaphors of Big Data”, International Journal of Communication, 8 (1): 1690-1709.

Silva, G. C. 2018. "Para repensar comunicação e Big Data: situando caminhos a partir da edição especial do Journal of Communication", Revista do Edicc, 5 (5): 107-118.

Swan, M. 2015. "Philosophy of Big Data: expanding the human-data relation with Big Data science services", in IEEE Computer Society. Proceedings of the 2015 IEEE First International Conference on Big Data Computing Service and Applications. Redwood City, 30 March - 2 April. Washington DC: IEEE.

Thomson, I. 2000. "Ontotheology? Understanding Heidegger's destruktion of metaphysics", International Journal of Philosophical Studies, 8 (3): 297-327.

Tomaz, T. 2017. Máquina como Outro comunicativo: crítica da concepção cibernética à luz da fenomenologia de Heidegger. $\mathrm{PhD}$. Universidade de São Paulo.

Wheeler, M. 2020. Martin Heidegger, in Zalta, E. N. (ed.). The Stanford Encyclopedia of Philosophy. Stanford: Stanford University Press. Available at: <https://plato.stanford.edu/ archives/fall2020/entries/heidegger/> [Accessed 30 June. 2021].

Guilherme C. Silva, Tales Tomaz BIG DATA KAIP „PRAKTINĖ ONTOLOGIJA“:
ONTOTEOLOGIJA, KURIA GRINDŽIAMA TIKROVÉS
KAIP DUOMENŲ INTERPRETACIJA

Santrauka

Straipsnyje aptariamas „praktinès ontologijos“ atsiradimas kai kuriuose triumfalistiniuose diskursuose apie didžiuosius duomenis [Big Data]. Tokią interpretaciją galima kildinti iš Martino Heideggerio ontoteologijos kritikos - termino, kurị jis vartojo kaip Vakarų metafizikos atitikmeni. Vadovaujantis jo perspektyva, straipsnyje teigiama, kad tikrovès redukavimas ị duomenis, kaip tai daroma daugelyje didžiųjų duomenų diskursų, reiškia, kad funkcionalumas laikomas esminiu būtybių aspektu, taigi ir praktinès ontologijos idèja. Tačiau Heideggerio ontoteologijos kritika ne tik daro skaidresnị praktinių didžiųjų duomenų diskursų ontologinị branduolị, bet ir nurodo teorines šios ontologijos, o kartu ir daugumos su didžiaisiais duomenimis susijusių diskursų, ribas. Galiausiai galima teigti, kad praktinè didžiųjų duomenų ontologija slepia patị būtybių kaip duomenų nepaslëpties momentą, kenkdama tinkamam jos analizès objekto - duomenų - suvokimui.

RAKTAŽodžıAI: Big Data, praktinė ontologija, Martinas Heideggeris, metafizika. 